\title{
Imatinib Inhibits Proliferation of Ewing Tumor Cells Mediated by the Stem Cell Factor/KIT Receptor Pathway, and Sensitizes Cells to Vincristine and Doxorubicin-Induced Apoptosis
}

\author{
Iranzu González, ${ }^{1}$ Enrique J. Andreu, ${ }^{2}$ \\ Angel Panizo, ${ }^{3}$ Susana Inogés, ${ }^{2}$ Ana Fontalba, ${ }^{6}$ \\ José Luis Fernández-Luna, ${ }^{6}$ Mirella Gaboli, ${ }^{4}$ \\ Luis Sierrasesúmaga, ${ }^{4}$ Salvador Martín-Algarra, ${ }^{5}$ \\ Javier Pardo, ${ }^{3}$ Felipe Prósper, ${ }^{2}$ and \\ Enrique de Alava $^{7}$ \\ ${ }^{1}$ Department of Histology and Pathology, School of Medicine- \\ Universidad de Navarra, Pamplona, Spain; ${ }^{2}$ Area of Cell Therapy, \\ Departments of ${ }^{3}$ Pathology, ${ }^{4}$ Pediatrics, and ${ }^{5}$ Oncology, Clínica \\ Universitaria de Navarra-Universidad de Navarra, Pamplona, Spain; \\ ${ }^{6}$ Molecular Genetics Unit, Hospital Universitario Marqués de \\ Valdecilla, Escuela de Enfermería, Santander, Spain; and ${ }^{7}$ Laboratory \\ 20-Molecular Pathology, Centro de Investigación del Cáncer, \\ Universidad de Salamanca-CSIC, Campus Miguel de Unamuno s/n, \\ Salamanca, Spain
}

\section{ABSTRACT}

Purpose and Experimental Design: The stem cell factor/ KIT receptor loop may represent a novel target for molecular-based therapies of Ewing tumor. We analyzed the in vitro impact of KIT blockade by imatinib in Ewing tumor cell lines.

Results: KIT expression was detected in 4 of 4 Ewing tumor cell lines and in 49 of 110 patient samples $(\mathbf{4 4 . 5 \% )}$ by immunohistochemistry and/or Western blot analysis. KIT expression was stronger in Ewing tumors showing $E W S$ FLI1 nontype 1 fusions. Despite absence of c-kit mutations, constitutive and ligand-inducible phosphorylation of KIT was found in all tumor cell lines, indicating an active receptor. Treatment with KIT tyrosine kinase inhibitor imatinib (0.5-20 $\mu \mathrm{M})$ induced down-regulation of KIT phosphorylation and dose response inhibition of cell proliferation $\left(\mathrm{IC}_{50}\right.$, 12-15 $\mu \mathrm{M})$. However, imatinib administered alone at doses close to $\mathrm{IC}_{\mathbf{5 0}}$ for growth inhibition $(10 \mu \mathrm{M})$ did not induce a significant increase in apoptosis. We then analyzed if blockade of KIT loop through imatinib $(10 \mu M)$ was able to increase the antitumor in vitro effect of doxorubicin (DXR)

Received 5/22/03; revised 9/8/03; accepted 9/24/03.

Grant support: Grants FIS 02/0828 (to E. d. A.) and FIS 01/0013-01 (to F. P.) from the Ministry of Health of Spain, (Madrid, Spain).

The costs of publication of this article were defrayed in part by the payment of page charges. This article must therefore be hereby marked advertisement in accordance with 18 U.S.C. Section 1734 solely to indicate this fact.

Note: Enrique J. Andreu is a fellow of the "Fundación Española de Hematología y Hemoterapia."

Requests for reprints: Enrique de Alava, Laboratory 20-Molecular Pathology, Centro de Investigación del Cáncer, Universidad de Salamanca-CSIC, Campus Miguel de Unamuno s/n, E-37007 Salamanca, Spain. Phone: 34-923-294820; Fax: 34-923-294743. and vincristine (VCR), drugs usually used in Ewing tumor treatment. Addition of imatinib decreased in 15-20 and $15-36 \%$ of the proliferative rate of Ewing tumor cells exposed to DXR and VCR, respectively, and increased in $\mathbf{1 5}$ and $30 \%$ of the apoptotic rate of Ewing tumor cells exposed to the same drugs.

Conclusions: Inhibition of Ewing tumor cell proliferation by imatinib is mediated through blockade of KIT receptor signaling. Inhibition of KIT increases sensitivity of these cells to DXR and VCR. This study supports a potential role for imatinib in the treatment of Ewing tumor.

\section{INTRODUCTION}

Ewing tumor is a highly aggressive neoplasm preferentially diagnosed in bone and soft tissues of children and young adults, which show 5-year survival rates of only $50 \%$ despite the use of multimodal therapeutic approaches (1). Since the early 1980s, improved outcomes were reported with the inclusion of doxorubicin (DXR), nearly every chemotherapy protocol for Ewing tumor included at least doxorubicin and vincristine (VCR; Ref. 2 ). Growth of clinically detectable metastases, present in $\sim 30 \%$ of patients at diagnosis, represents the most adverse prognostic factor (2). Results are particularly unfavorable in patients with metastases to bone and/or bone marrow; dose-intensive use of the chemotherapy agents with established activity in Ewing tumor is reaching its efficacy and toxicity limits in these particular cases (3). Search for new therapeutic targets and development of novel therapeutic modalities are therefore needed for treatment of these subsets of patients with Ewing tumor.

Ewing tumor is characterized by the presence of chimeric proteins that fuse the $\mathrm{NH}_{2}$-terminal domain of the RNA-binding protein EWS, with the DNA binding moiety of an ETS transcription factor (FLI-1 in $90 \%$ of cases; Ref. 4-11). Extensive experimental data exist that demonstrate the oncogenic potential of EWS-ETS fusions $(12,13)$. Ewing tumor proliferation and survival is also determined by autocrine and paracrine activation of growth factor receptors and their ligands, including insulinlike growth factor I, gastrin-releasing peptide, and their receptors $(14,15)$. KIT and its ligand stem cell factor (SCF) represent an additional example of an autocrine loop in Ewing tumor. Stimulation with SCF induces tyrosine autophosphorylation of KIT and of a number of mediators involved in the subsequent intracellular signaling, including phosphatidylinositol 3'-kinase, and mitogen-activated protein kinase (MAPK; Ref. 16). Neoplastic transformation has been established via mutation of c-kit gene, which results in ligand-independent activation of the receptor in a number of human tumors such as human mast cell tumors $(17,18)$, chronic myelogenous leukemia (19), germ cell tumors (20), and gastrointestinal stromal tumors (GISTs; Refs. 21-23). Overexpression of SCF and KIT has been demonstrated in a number of malignancies (small cell lung carcinoma, ovarian 
carcinoma, breast carcinoma, and melanoma; Ref. 24) and in Ewing tumor cell lines $(25,26)$. In most cases, the role of the SCF/KIT loop in supporting the proliferation and/or survival of these tumors has not been well established. Recent in vitro studies suggest that SCF induces proliferation of Ewing tumor cell lines and increases their metastatic potential (26) and show that KIT blockade by high doses $(20 \mu \mathrm{M})$ of imatinib in serumdeprived cells induces apoptosis (27).

Imatinib (Gleevec; Novartis Pharmaceuticals, Basel, Switzerland) is a tyrosine-kinase inhibitor that selectively blocks tyrosine phosphorylation of KIT and platelet-derived growth factor receptors $\alpha$ and $\beta$. Imatinib inhibits BCR-ABL kinase activity in patients with chronic myelogenous leukemia $(28,29)$ and is also active in patients with GISTs in which mutations of the c-kit gene result in a constitutively activated receptor (3032). This compound may have clinical use in other neoplasms in which KIT is involved in proliferative or antiapoptotic responses.

In the current study, two basic questions were addressed: which is the expression and function of KIT receptor in Ewing tumor samples and cell lines, and which is the effect of Imatinib alone and in combination on proliferation and apoptosis of Ewing tumor cells? Our results support a potential role of imatinib in the treatment of this neoplasm.

\section{MATERIALS AND METHODS}

Cell Lines and Clinical Samples. SK-ES-1 (a gift from Dr. Santiago Ramón y Cajal, Vall d'Hebron Hospital, Barcelona, Spain), with a type 2 EWS-FLI-1 fusion was routinely cultured in McCoy's medium (Biochrom KG) with 15\% heatinactivated fetal serum (Life Technologies, Inc.). A673, obtained from the European Collection of Animal Cell Cultures, with a EWS-FLI-1 type 1 fusion was routinely cultured in DMEM (Life Technologies, Inc.) with 10\% heat-inactivated fetal serum. TC-71, with a EWS-FLI-1 type 1 fusion, and A4573, with a EWS-FLI-1 type 3 fusion (a gift from Dr. Samuel Navarro, Universidad de Valencia, Spain), were cultured in Iscove's modified Dulbecco's medium (Life Technologies, Inc.) with $20 \%$ heat-inactivated fetal serum.

A total of 110 formalin-fixed, paraffin-embedded Ewing tumor consecutive samples from 78 patients (49 males and 29 females; mean age at diagnosis 18 years) was available for immunohistochemical study in our institution's files. Snapfrozen tissue was available in 42 samples; EWS-ETS transcript determination was performed as reported elsewhere (33). The study was approved by the Local Ethics Committee.

Expression Analysis (Reverse Transcription-PCR). Total RNA was extracted from cell lines and Ewing tumor clinical samples by using Ultraespec RNA (Biotecx Laboratories, Inc.). cDNA was obtained by using $1 \mu \mathrm{g}$ of total RNA. Conditions used for reverse transcription, c-kit and SCF amplification, and PCR primers were reported previously (34).

SCF and c-kit Sequencing. Sequencing of the whole coding region of c-kit and SCF was performed in all Ewing tumor cell lines and in four Ewing tumor clinical samples. cDNA was amplified using Platinum TaqDNA polymerase high fidelity (11304-011; Invitrogen) and previously reported primers (17). Purified PCR fragments were fully sequenced with sense and antisense primers by fluorescence-based dideoxy terminator cycle sequencing (Beckman Coulter, Fullerton, CA). Data collection and analysis were performed on an automated DNA sequencer (CEQ 2000XL DNA Analysis System; Beckman Coulter). GNNK $+/-$ receptor isoforms were previously cloned in the plasmid vector pCR4-TOPO (Invitrogen) and then sequenced with T3 and T7 primers as described above.

Western Blot and Immunoprecipitation Analysis. The expression of KIT was determined by Western blotting in all cell lines and in four Ewing tumor clinical samples. For protein extraction, cells were scraped off the dish, pelleted, washed twice in cold PBS, resuspended in radioimmunoprecipitation assay buffer, incubated $30 \mathrm{~min}$ on ice, and then centrifuged at $13,000 \times g$ for $15 \mathrm{~min}$ at $4^{\circ} \mathrm{C}$. Protein concentration for each lysate was determined using the BCA Protein Assay Reagent (Pierce). Proteins $(50 \mu \mathrm{g} / \mathrm{lane})$ were resolved on $8 \%$ SDSPAGE, transferred to nitrocellulose membranes, incubated with specific antibodies, and visualized by enhanced chemiluminescence (Tropix). Anti-KIT polyclonal antiserum (A4502; Dako Cytomation) was diluted 1:500.

Blots were stripped and reprobed with a $\beta$-actin antibody (Sigma Chemical Co., Poole, United Kingdom) as a protein loading control. KIT-containing complexes were immunoprecipitated in Ewing tumor cell lines from $300 \mu \mathrm{g}$ of protein extracts with $1 \mu \mathrm{g}$ of antibody and $20 \mu \mathrm{l}$ of Protein A/G-plusAgarose (Santa Cruz Biotechnology Biotech). Immunoprecipitates were washed five times with NET buffer. Samples then underwent elution from Protein A/G, electrophoresis, and transfer to nitrocellulose. Filters were incubated first with mouse antiphosphotyrosine (Upstate Biotechnology). Nitrocellulose filters were stripped of antibody using $0.5 \mathrm{~m}$ Tris- $\mathrm{HCl}(\mathrm{pH} 6.8)$, $10 \% \mathrm{SDS}$, and $0.75 \% \beta$-mercaptoethanol at $65^{\circ} \mathrm{C}$ for $30 \mathrm{~min}$ and then reprobed with polyclonal antibody anti-KIT (A4502; Dako Cytomation).

Antibodies used to characterize phosphorylation status of KIT signaling pathway were: phospho-p44/p42 MAPK (Thr ${ }^{202} /$ $\mathrm{Tyr}^{204}$ ) antibody (catalogue no. 9101), p44/42 MAPK antibody (catalogue no. 9102), phospho-AKT $\left(\mathrm{Ser}^{473}\right.$ ) antibody (catalogue no. 9271), and AKT antibody (catalogue no. 9270); all antibodies were obtained from Cell Signaling Technology.

Immunohistochemistry. Formalin-fixed, paraffinembedded sections were incubated overnight at room temperature with polyclonal anti KIT antibody (A4502, dilution 1:100; Dako Cytomation) and with phospho-KIT $\left(\mathrm{Tyr}^{719}\right.$; polyclonal, code 3391; dilution 1:50; Cell Signaling Technology, Inc., Beverly, MA). Staining was performed with the EnVision+ system (Dako Cytomation). Antigen retrieval using buffer citrate $(\mathrm{pH}$ 7.0), and microwave treatment for $20 \mathrm{~min}$ in an 800-W microwave oven was performed. Sections of several GISTs were used as controls. Results were evaluated by two independent observers (E. d. A. and A. P.) blinded to clinicopathological and molecular data. The number and intensity of immunoreactive cells were evaluated in three randomly selected fields. The number was expressed as the percentage of reactive cells. Intensity of staining was scored + to $+++(+$ meant faint staining intensity with incomplete membrane staining; +++ meant intense and complete membrane staining). We considered immunoreactivity over $50 \%$ of cells as diffuse staining and +++ intensity as strong staining. 
A

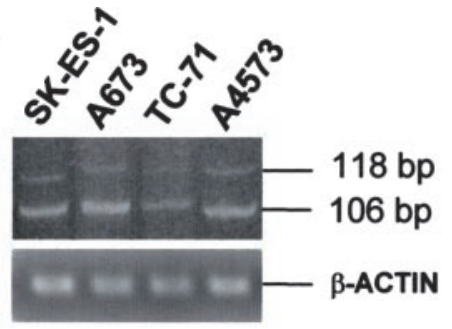

B

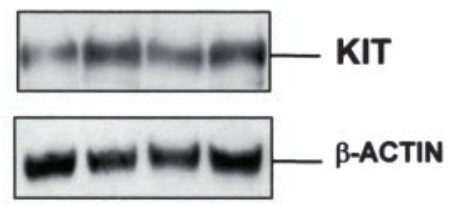

C

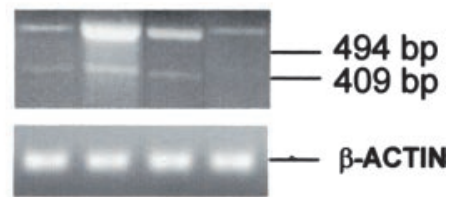

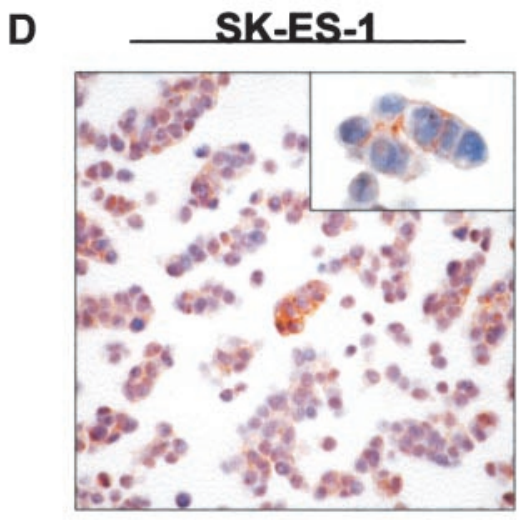

E

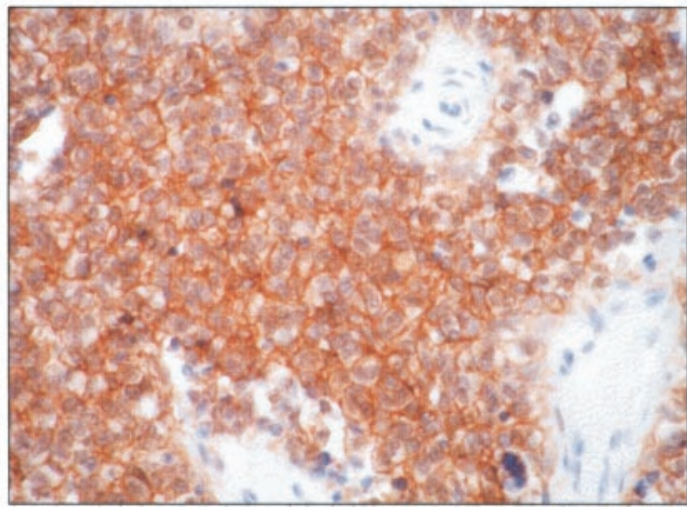

F

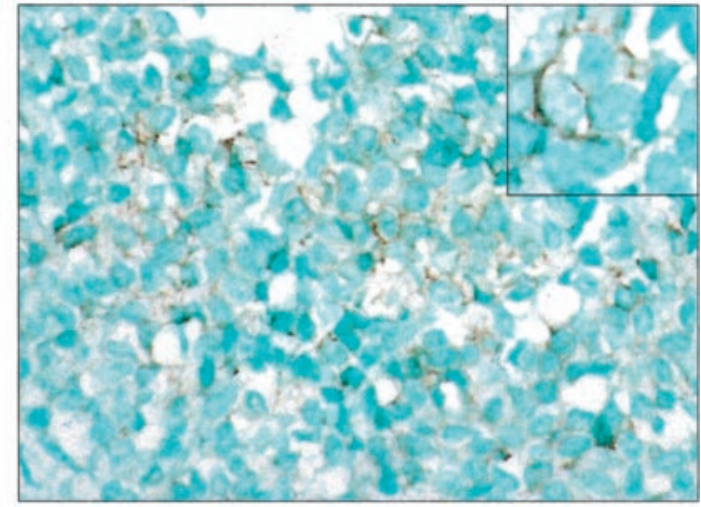

Fig. 1 KIT/stem cell factor (SCF) expression in Ewing tumor cell lines, and KIT expression in clinical samples of Ewing tumors: A, reverse transcription-PCR for c-kit. Expression of c-kit mRNA was found in all Ewing tumor cell lines studied. Bands at 106 and 118 bp, corresponding to GNNK + and GNNK - isoforms, were found in all samples. B, Western blotting for KIT; a single band of 145 KDa was found in all cell lines. $C$, reverse transcription-PCR for SCF. Expression of mRNA for SCF was found in all cell lines. A band at $409 \mathrm{bp}$ (transmembrane isoform) was detected with a consistent level of expression in all cell lines, except in A4573, which was almost negative; a band of 494 bp (soluble isoform) was found in all Ewing tumor cell lines. D, immunohistochemical detection of KIT (see "Materials and Methods" for details) in SK-ES-1 cell line, showing reactivity in the plasma membrane $(\times 300$; inset, $\times 1000)$. E, representative immunohistochemical analysis of KIT receptor in paraffin-embedded tissue of a Ewing tumor. Note that reactivity shows a plasma membrane distribution; $F$ represents detection of phosphorylated tyrosine at residue 719 of KIT receptor in the same sample. $(\times 400$; inset, $\times 1000)$.

Table 1 KIT expression and EWS-FLII transcript type ${ }^{a}$

\begin{tabular}{lrrr}
\hline & \multicolumn{2}{c}{$\begin{array}{c}\text { Strong and } \\
\text { diffuse KIT }\end{array}$} & \\
\cline { 2 - 3 } & No & Yes & Total \\
\cline { 2 - 3 } & Nossion & \\
\hline Transcript type & 18 & 4 & 22 \\
EWS-FLII type 1 & 5 & 13 & 18 \\
EWS-FLI1 nontype 1 & 23 & 17 & 40 \\
Total & 5 & & \\
\hline
\end{tabular}

${ }^{a} P=0.010$ (Pearson's $\chi^{2}$ test-Fisher's exact test).
Proliferation Assay. Three different assays were performed in complete medium to mimic the effect of imatinib in human tumors. First, dose response proliferation studies with imatinib $(0.5-20 \mu \mathrm{M})$ were performed to assess the degree of inhibition provoked by the drug. Cells (2000 cells/well) were seeded in a 96-well cell culture and, after $48 \mathrm{~h}$, were treated with imatinib $(0.5-20 \mu \mathrm{M})$ for $24 \mathrm{~h}$. To verify that KIT inhibition by imatinib was not reverted by ligand stimulation, a second assay was performed in which cells were treated under different conditions as follows: imatinib $(10 \mu \mathrm{M})$ for $12 \mathrm{~h}$; imatinib (10 

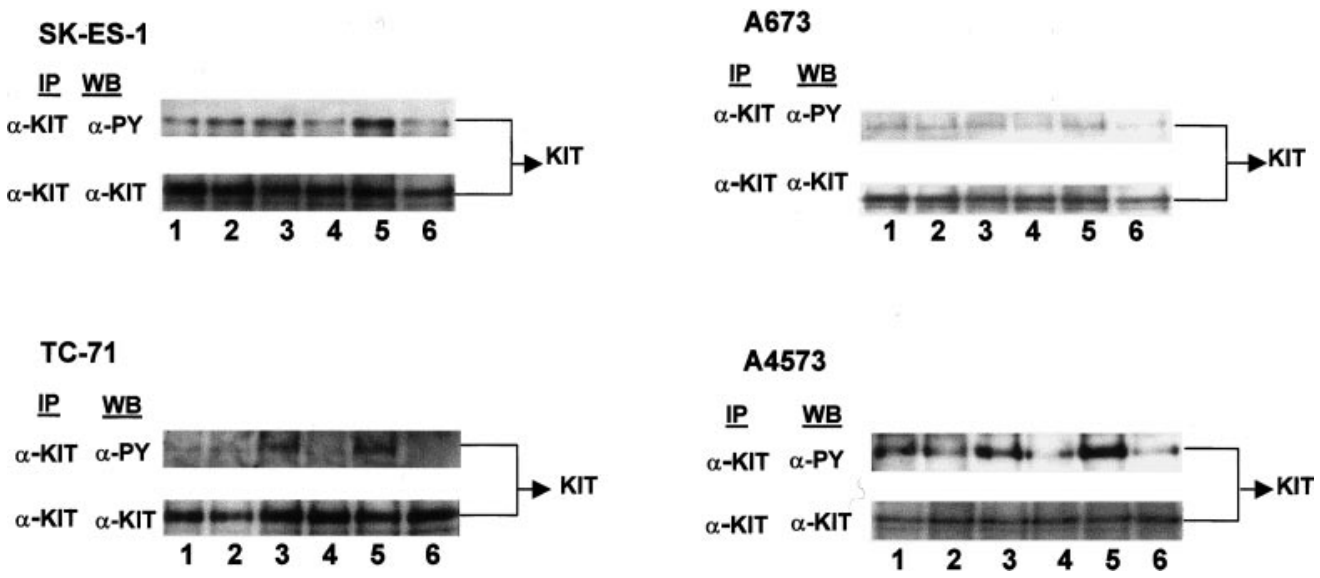

Fig. 2 Functionality of KIT receptor. Immunoprecipitation studies were performed in all cell lines under different conditions, including SCF stimulation during 1 and $5 \mathrm{~min}$, with and without imatinib $(10 \mu \mathrm{M})$. Filters were incubated first with mouse antiphosphotyrosine (top gels) to assess the degree of phosphorylation of the receptor. All cell lines showed basal KIT phosphorylation level in FBS-free conditions showing a functional autocrine loop KIT/stem cell factor (SCF) (Lane 1, FBS -). Receptor was also active in presence of FBS (Lane 2, FBS +). Receptor phosphorylation increased after incubation with exogenous SCF after a 1-min treatment (Lane 3, SCF 1 min) or a 5-min treatment (Lane 5; SCF 5 min). Phosphorylation was higher after 5-min treatment (Lane 5). Imatinib treatment (10 $\mu \mathrm{M})$ provoked a decrease of SCF-induced KIT phosphorylation in all cell lines. Kinase activity of the receptor was markedly inhibited by imatinib pretreatment. (Lane 4, $10 \mu \mathrm{M}$ imatinib/SCF $1 \mathrm{~min}$, and Lane 6 , $10 \mu \mathrm{M}$ imatinib/SCF $5 \mathrm{~min}$ ). Filters were then stripped and reprobed with polyclonal antibody anti KIT (bottom gels) to control for lane load. Bands of similar intensity confirmed that equal amounts of protein were loaded in each experimental sample. IP, immunoprecipitation; WB, Western blotting.

$\mu \mathrm{M})$ for $6 \mathrm{~h}$ and then combined with $\mathrm{SCF}(10 \mu \mathrm{g} / \mathrm{ml})$ for 6 additional $\mathrm{h}$; and SCF $(10 \mu \mathrm{g} / \mathrm{ml})$ alone for $6 \mathrm{~h}$. A third assay was performed to test if KIT inhibition would increase sensitivity of these cells to chemotherapy. Cells were seeded as described above and treated with varying concentrations of DXR (range, 5-20 ng/ml) or VCR (range, 0.5-2.5 ng/ml) for $24 \mathrm{~h}$ with imatinib (range, $0.625-10 \mu \mathrm{M}$ ) or without it (control). Tritiated thymidine incorporation assay was used as a measure of proliferation. Three replicate experiments were performed for each cell line.

Apoptosis Studies. Apoptosis was measured after imatinib treatment $(10-20 \mu \mathrm{M})$ for $12-72 \mathrm{~h}$. To test cytotoxicity of imatinib in combination with standard therapy, imatinib $(10 \mu \mathrm{M})$ was administered with DXR and VCR at $0.25 \mu \mathrm{g} / \mathrm{ml}$ and 5 $\mathrm{ng} / \mathrm{ml}$, respectively. The apoptotic index was assessed by flow cytometry using Annexin-V-FITC kit (Bender Medsystems, Vienna, Austria) following the manufacturer's instructions. Data acquisition and analysis were performed in a FACSort cytometer (Becton Dickinson, Heidelberg, Germany) using CellQuest Software (Becton Dickinson). For each analysis, 20,000 events were acquired on a forward and side scatter gate. All experiments were performed in complete medium.

Statistical Analysis. One-way ANOVA with HDS Tukey's test was used to detect differences in proliferation among groups. Pearson's $\chi^{2}$ test-Fisher's exact test were used to compare expression levels of KIT in patient samples with respect to EWS-FLI1 transcript type.

\section{RESULTS}

KIT Signaling Pathway Activation in Ewing Tumors Is Functional and Is Not Associated with Receptor Mutations. All Ewing tumor-derived cell lines expressed mRNA of the two alternative spliced forms of c-kit (Fig. 1A). Sequencing of both

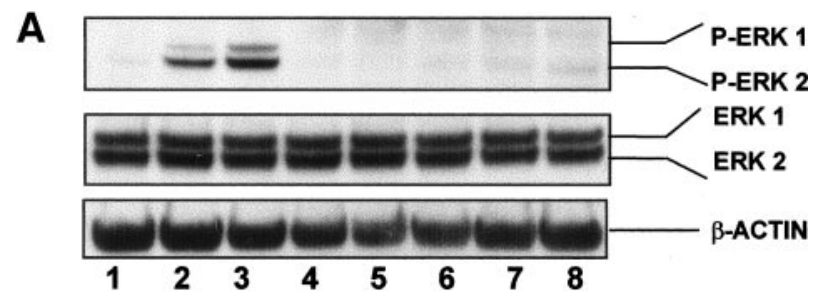

B

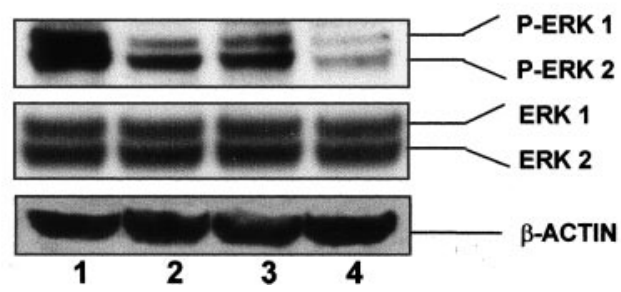

Fig. 3 Extracellular signal-regulated kinase (ERK) 1/2 signaling pathway activation. A, top blot, ERK $1 / 2$ time course activation after stem cell factor (SCF) stimulation. ERK signaling pathway was specifically induced by SCF. In A673 cell line, $p$-ERK 1/2 was detected after 5 and $15 \mathrm{~min}$ of stimulation (Lanes 2 and 3, respectively). The maximal activity induction was found after $15 \mathrm{~min}$ of SCF stimulation (Lane 3). ERK 1/2 phosphorylation was undetectable at longer time exposures (Lane 4, $30 \mathrm{~min}$; Lane 5, 1 h; Lane 6, 2 h, and Lane 7, 3 h). Lanes 1 and 8 correspond to controls included in the experiment as follows: Lane 1, ERK $1 / 2$ activity at $0.4 \%$ FBS concentration, and Lane 8, ERK 1/2 activation at complete medium (FBS 20\%). Bottom blot: total ERK 1/2 protein. No changes in protein expression were found after SCF stimulation. Total ERK 1/2 expression and $\beta$-actin were used to control for protein loading. $B$, top blot: $p$-ERK $1 / 2$ detection in Ewing tumor clinical samples (Lanes 1-4). All cases presented strong mitogenactivated protein kinase signaling activation. Bottom blot: total ERK 1/2 protein detection in Ewing tumor clinical samples. Total ERK 1/2 expression and $\beta$-actin were used to control for protein loading. 


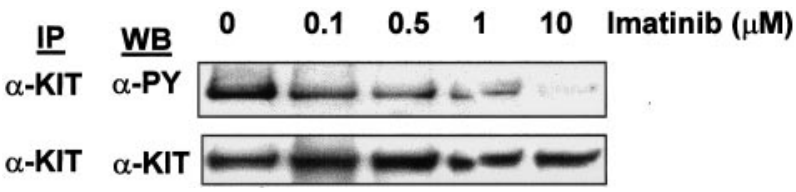

Fig. 4 Inhibition of KIT kinase activity after imatinib treatment. Imatinib treatment provoked a marked inhibition in receptor phosphorylation in a dose-dependent manner. This figure shows phosphorylation status of KIT with different concentrations of imatinib $(0,0.1,0.5,1$, and $10 \mu \mathrm{M})$ in presence of stem cell factor. IC $_{50}$ for KIT kinase activity was $\sim 0.5-1 \mu \mathrm{M}$. At $10 \mu \mathrm{M}$ imatinib, receptor activity was completely blocked. IP, immunoprecipitation; WB, Western blotting.

bands confirmed GNNK + and GNNK - isoforms. c-kit expression was also found by reverse transcription-PCR in clinical samples (data not shown). Sequencing of the coding region of c-kit also showed a previously reported isoform lacking three nucleotides, $2164 \mathrm{~A}, 2165 \mathrm{G}$, and $2166 \mathrm{C}$, corresponding to a codon in the mid-segment of the split-kinase domain (exon 15), encoding serine in position 715. Expression of KIT was also demonstrated at the protein level (Western blot and immunohistochemistry) in all four cell lines (Fig. 1, $B$ and $D$, respectively). mRNA from both SCF isoforms, soluble (including exon 6) and transmembrane (lacking exon 6), were expressed in all cell lines (Fig. 1C). Sequencing of PCR fragments revealed germ-line SCF. To demonstrate the expression of KIT receptor in Ewing tumor biopsy material, we performed immunohistochemistry in 110 samples. In 49 of them, strong and diffuse staining was seen including the plasma membrane and/or the cytoplasm (Fig. 1E), whereas in 41 samples, staining showed a weak nuclear pattern. Scattered mast cells, immunoreactive with KIT, were found in several samples and were useful as a positive internal control; all GISTs showed strong and diffuse staining. There was no relationship of KIT staining with gender, age, metastasis at diagnosis, and tumor location. EWS-FLI1 fusions were found in 40 patients (in 22 were type 1 , and 18 had nontype 1), and $E W S-E R G$ in 2 patients. The samples showing $E W S$-FLI-1 nontype 1 fusions had strong and diffuse staining for KIT more frequently than those having EWS-FLII type 1 transcripts (Table $1 ; P=0.01$ Pearson's $\chi^{2}$ test-Fisher's exact test).

Ewing tumor cell lines and clinical samples showed SCF/ KIT pathway phosphorylation. As shown in Fig. 2, all cell lines presented a basal level of KIT phosphorylation either in medium supplemented with fetal bovine serum or in serum-free medium (supplemented with insulin, transferrin, and selenium). Receptor phosphorylation increased in all cell lines after treatment with exogenous SCF (Fig. 2). KIT activation was rapidly induced after 1- or 5-min SCF stimulation. Accordingly, 11 Ewing tumor samples showed immunoreactivity for phospho-KIT $\left(\mathrm{Tyr}^{719}\right.$; Fig. $1 F$ ) decorating the plasma membrane; mast cells, immunoreactive for Phospho-KIT, served as internal control; all GISTs were negative. Phospho-KIT $\left(\mathrm{Tyr}^{719}\right)$ antibody specificity was evaluated on three frozen clinical samples of Ewing tumor. Cell lysates were immunoprecipitated with a polyclonal KIT antibody, and Western blotting analysis was then performed using phospho-KIT $\left(\mathrm{Tyr}^{719}\right)$ antibody, followed by total KIT detection. All of them showed a $145-$ KDa band after Western blot- ting, indicating KIT phosphorylation in $\mathrm{Tyr}^{719}$ residue (data not shown).

Moreover, members of the MAPK signaling pathway, extracellular signal-regulated kinase (ERK)1 and ERK2, showed activation between 5 and $15 \mathrm{~min}$ after SCF stimulation (Fig. $3 A$ ). Analogously, p-ERK1/2 was detected (Fig. $3 B$ ) in all four primary Ewing tumors.

Sequencing results of c-kit revealed absence of mutations in Ewing tumor cell lines and clinical samples. These results show that in Ewing tumor cell lines and clinical samples SCF/ KIT pathway is active, despite the absence of activating mutations of c-kit.

Imatinib-Mediated Inhibition of KIT Receptor Prevents Ewing Tumor Cell Proliferation but Does Not Induce Significant Apoptosis at Clinically Relevant Doses. To assess if SCF-KIT pathway participates in proliferation of Ewing tumor cells and whether imatinib may have a role in the treatment of patients with Ewing tumor, we analyzed KIT activity and the proliferative rate of Ewing tumor cell lines after exposure to imatinib. As shown in Fig. 2, imatinib $(10 \mu \mathrm{M})$ treatment caused an irreversible decrease of spontaneous and SCF-

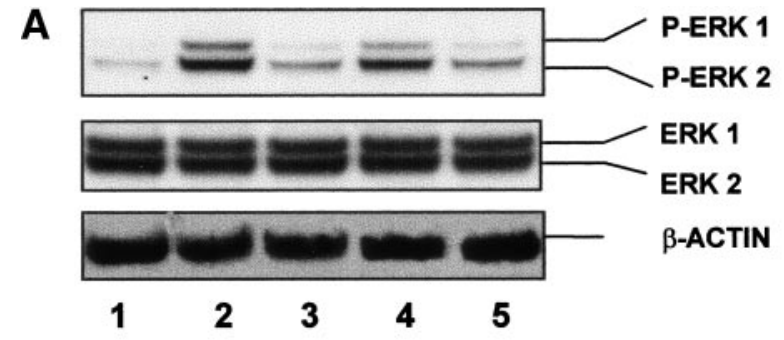

B

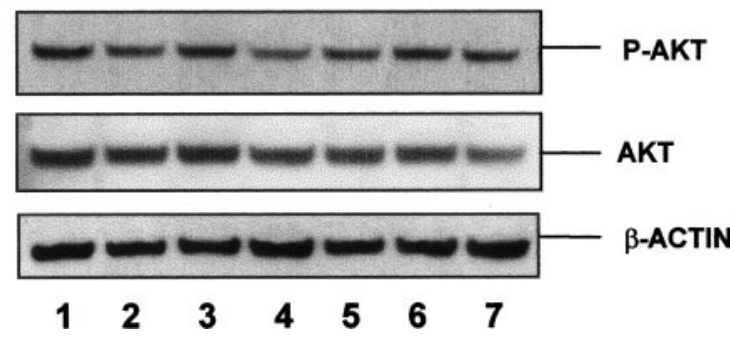

Fig. 5 Imatinib mediated inhibition of signal transduction pathway triggered by KIT. A, Top blot: stem cell factor (SCF)-induced extracellular signal-regulated kinase (ERK) $1 / 2$ phosphorylation was partially inhibited with imatinib pretreatment in A673 cell line. After 5 and 15 min of SCF treatment (Lanes 2 and 4, respectively), signaling pathway triggered by KIT was activated, showing $p$-ERK $1 / 2$ phosphorylation. However, imatinib pretreatment was able to block the signaling cascade carried out by KIT as shown by the decrease in ERK $1 / 2$ phosphorylation (Lanes 3 and 5): Lane 3, $10 \mu \mathrm{M}$ imatinib/SCF (5 min), and Lane $5,10 \mu \mathrm{M}$ imatinib/SCF (15 min). Lane 1: ERK $1 / 2$ activity at $0.4 \%$ FBS concentration. Bottom blot: total ERK 1/2 protein; no changes in protein expression were found after SCF stimulation. Total ERK $1 / 2$ expression and $\beta$-actin were used to control for protein loading. $B$, Top blot: $p$-AKT detection after imatinib treatment in A673. No changes in AKT phosphorylation levels were found after imatinib treatment. Lane 1, FBS; Lanes 2-4, $10 \mu \mathrm{M}$ imatinib for 12, 24, and $48 \mathrm{~h}$, respectively; and Lanes 5-7, $20 \mu \mathrm{M}$ imatinib for 12, 24, and $48 \mathrm{~h}$, respectively. Experiments were performed in complete medium. Bottom blot: total AKT protein; no changes in protein expression were found after imatinib treatment Equal amounts of protein were loaded. 


\section{GROWTH INHIBITION}

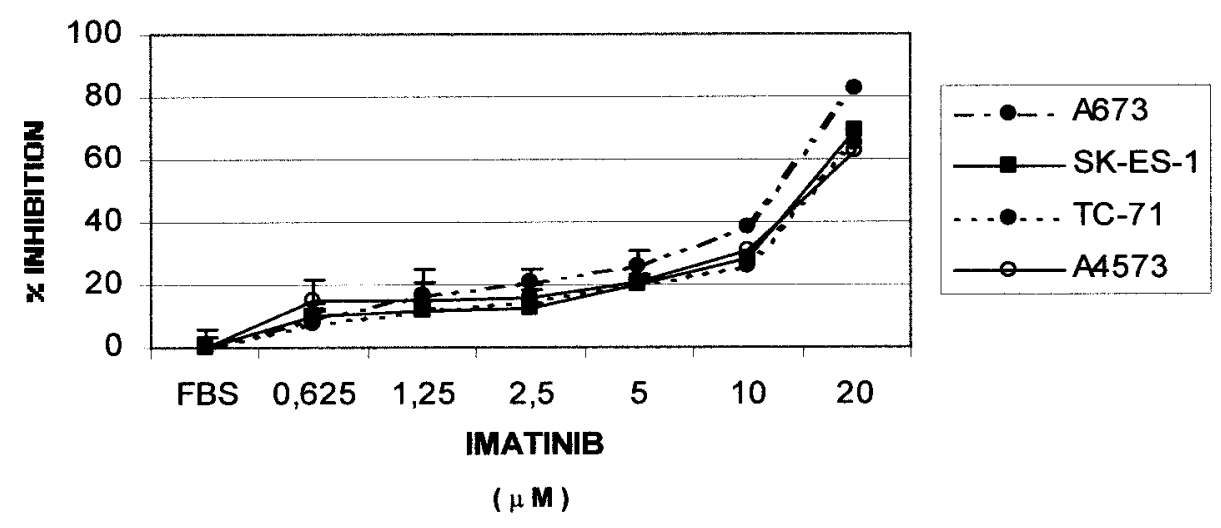

Fig. 6 Growth inhibition mediated by imatinib dose response analysis of imatinib in Ewing tumor cell lines. Cells at a density of 2000 cells/well were seeded in a 96-well cell culture plate in culture medium with FBS and then treated with imatinib $(0.625-20 \mu \mathrm{M})$ for $24 \mathrm{~h}$. A marked decrease in thymidine incorporation was found in all Ewing tumor cell lines after imatinib. Growth inhibition was dose dependent, being more pronounced over $10 \mu \mathrm{M}$ imatinib. $\mathrm{IC}_{50}$ for cell proliferation ranged between 12 and $15 \mu \mathrm{M}$. induced KIT phosphorylation. Nevertheless, KIT activity inhibition was found at doses $<10 \mu \mathrm{M}$. In fact, $\mathrm{IC}_{50}$ for KIT kinase activity inhibition was $\sim 1 \mu \mathrm{M}$ imatinib (Fig. 4). Analogously, phosphorylation of ERK1/2, a downstream target of KIT signaling pathway, was also partially inhibited by imatinib (Fig. $5 A$ ), indicating that this drug effectively inhibits signal transduction triggered by KIT in Ewing tumor cell lines.

In addition, treatment with imatinib provoked a marked decrease in DNA synthesis after a 24- and 48-h treatment, which was dose dependent (Fig. 6). $\mathrm{IC}_{50}$ for cellular proliferation ranged between 12 and $15 \mu \mathrm{M}$.

The number of early apoptotic cells (Annexin-V +, propidium iodide -) did not show any significant increase in any cell line after $10 \mu \mathrm{M}$ imatinib treatment. Nevertheless, we found a mild increase (12\%) in Annexin V-positive cells after treatment of two cell lines, A673 and SK-ES-1, with higher imatinib concentrations ( $20 \mu \mathrm{M}$; data not shown). Accordingly, as shown in Fig. $5 B$, imatinib alone (10 or $20 \mu \mathrm{M}$ for 12,24 , and $48 \mathrm{~h}$ ) failed to inhibit constitutively AKT kinase, a crucial molecule in Ewing tumor cell survival modulation.

Increased Cytotoxicity of Combined in Vitro Treatments. We then investigated whether KIT kinase activity inhibition might increase cell susceptibility to chemotherapeutic drugs usually used for Ewing tumor treatment such as DXR and VCR. As shown in Figs. 7 and 8, the combined treatment with increasing concentrations of Imatinib $(0.625-10 \mu \mathrm{M})$ and DXR or VCR (dose ranging 5-20 ng/ml and $0.5-2.5 \mathrm{ng} / \mathrm{ml}$, respectively, depending on the particular sensitivity of the cell line to the drug) resulted in a higher growth inhibition in all cell lines than the observed with DXR or VCR alone. Cotreatment with DXR and imatinib resulted in a 15-20\% increase of antiproliferative effect with respect to the therapeutic efficacy of chemotherapy alone. Similar results were obtained with combinations of VCR and imatinib, which showed an increased toxicity of 15-36\%. Maximal inhibition was obtained using $10 \mu \mathrm{M}$ imatinib.

Imatinib, given at the same concentration that was unable to induce apoptosis when administered alone $(10 \mu \mathrm{M})$, enhanced toxicity caused by both chemotherapeutic agents in combined treatments (Figs. 9 and 10). Imatinib, combined with DXR (25 $\mu \mathrm{g} / \mathrm{ml})$ or VCR (5 ng/ml) in A673 cell line, increased in 15\%

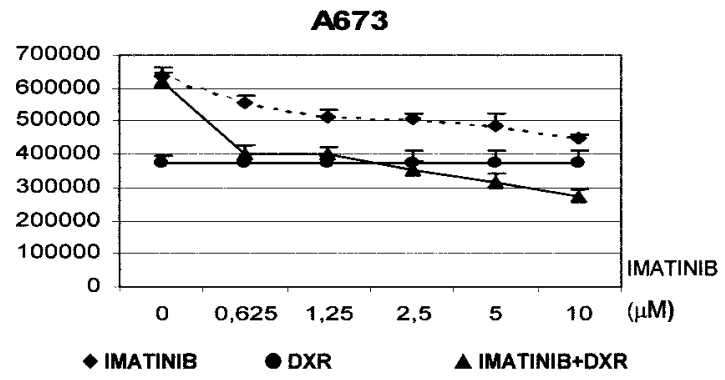

TC-71

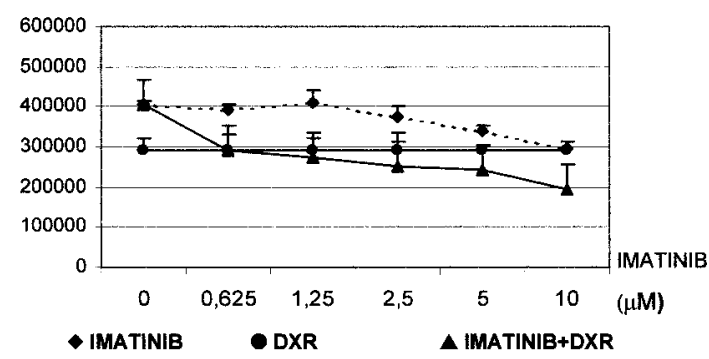

A4573

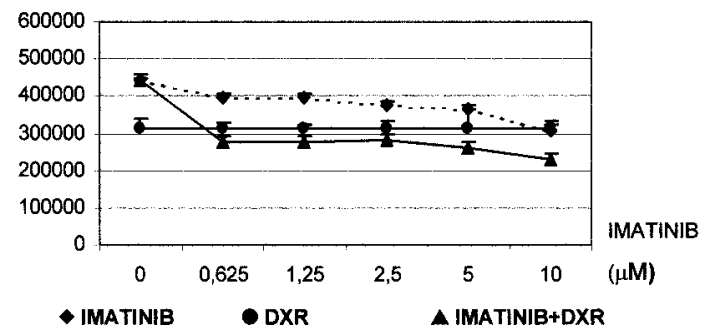

Fig. 7 Additive cytotoxicity of doxorubicin (DXR) in combination with imatinib on Ewing tumor cell lines. Combined treatment of imatinib with DXR resulted in a decrease of the proliferative rate of Ewing tumor cells with respect to controls (imatinib or DXR alone). Cells were treated with DXR alone $(-5-20 \mathrm{ng} / \mathrm{ml}$, depending on the sensitivity of cell line), imatinib alone ( ) at the mentioned concentrations, and with both drugs simultaneously for $24 \mathrm{~h}(\boldsymbol{\Lambda})$. Drug combination resulted in a decrease of between 15-20\% in thymidine incorporation with respect to DXR alone. Maximal effect in combined treatments was found at $10 \mu \mathrm{M}$ imatinib. Three replicate experiments were performed for each cell line. A representative experiment is shown in the figure. 
SK-ES-1

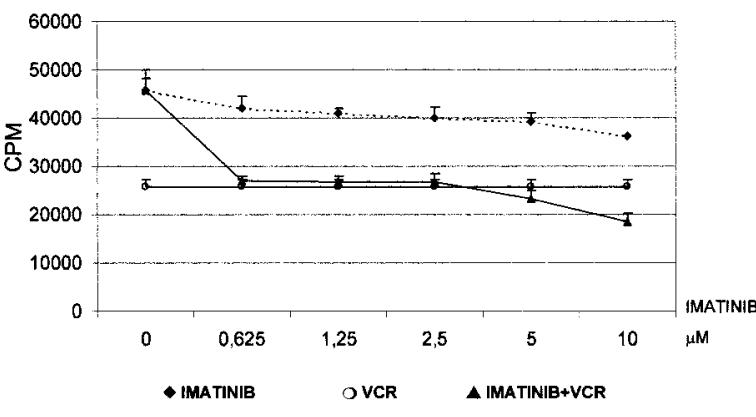

TC-71

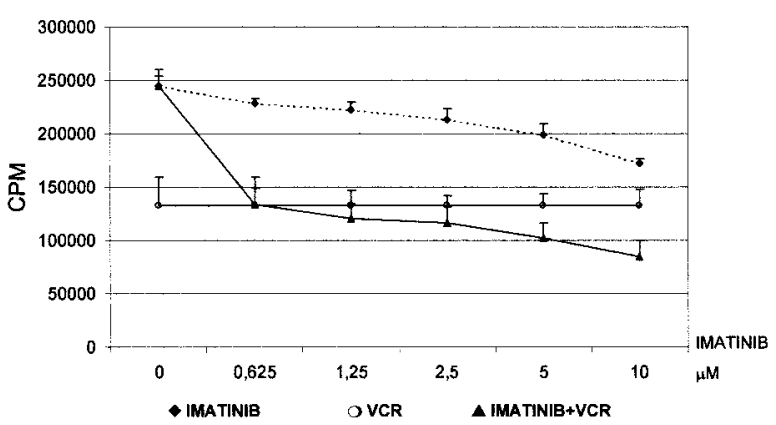

A673

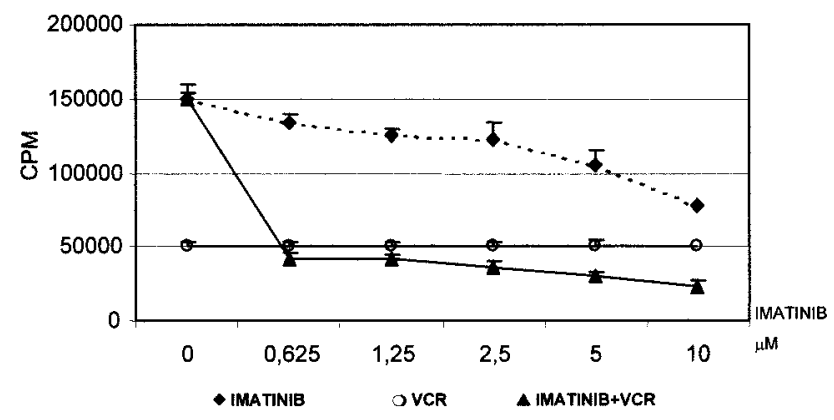

A4573

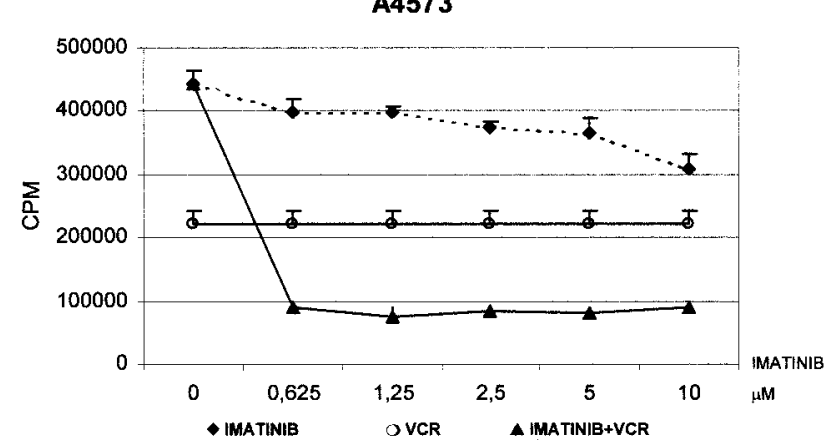

Fig. 8 Additive cytotoxicity of vincristine (VCR) in combination with imatinib on Ewing tumor cell lines. Thymidine incorporation assays showed again a higher cytotoxicity in combined treatments (VCR + imatinib) with respect to controls (VCR or imatinib alone). Cells were treated with VCR alone $(O ; 5-20 \mathrm{ng} / \mathrm{ml}$, depending on the sensitivity of cell line), imatinib alone $(\diamond)$ at the mentioned concentrations, and with both drugs simultaneously for $24 \mathrm{~h}(\mathbf{\Lambda})$. Drug combination resulted in a decrease of between $20-36 \%$ in thymidine incorporation with respect to VCR alone. Maximal effect in combined treatments was found at $10 \mu \mathrm{M}$ imatinib. Three replicate experiments were performed for each cell line. A representative experiment is shown in the figure.

(imatinib + DXR) or 30\% (imatinib + VCR) cellular apoptosis with respect to controls (DXR or VCR alone), showing that inhibition of the receptor pathway sensitized cells to conventional cytotoxic drugs, improving the antitumor activity of DXR and VCR.

\section{DISCUSSION}

As a first step to assess whether KIT is a potential therapeutic target in Ewing tumor, we confirmed that SCF/KIT autocrine loop components (35-39) are expressed in Ewing tumor cell lines and clinical samples (25-27). In the present study, all KIT isoforms were found to show a consistent level of expression in all cell lines $(36,40,41)$. Furthermore, almost half of clinical samples of Ewing tumor showed KIT immunoreactivity with membrane/cytoplasmic patterns. This to our knowledge is the largest series reported thus far of clinical samples of Ewing tumor in which KIT expression has been assessed by immunohistochemistry. Reported incidence of KIT reactivity in Ewing tumor biopsy specimens ranges between 29 and $71 \%$ (25, 42 ), depending on the technical conditions used in the study. Interestingly, we found that tumors having the most common type of EWS-FLI1 fusion transcript, type 1, had a lower degree of KIT expression than tumors having other fusion types. This particular fusion type is associated with a favorable prognosis (33) and to a lower expression of insulin-like growth factor I receptor (43), another membrane receptor relevant to Ewing tumor survival pathways. Our results could represent an additional biological basis for the relatively good prognosis of patients having EWS-FLI1 type 1 fusions.

KIT expression, however, does not necessarily equate with a functional and active receptor. We did not find any mutations in the whole coding region of c-kit of any of the cell lines and clinical samples studied. Importantly, despite the absence of mutations in the coding region of c-kit, our immunoprecipitation experiments showed that KIT is a functional receptor in Ewing tumor cell lines. A basal phosphorylation level was found in all cell lines in presence of FBS as well as in serum-free medium, suggesting a functional autocrine loop SCF/KIT. Furthermore, all cell lines showed a marked KIT phosphorylation increase in presence of exogenous SCF, indicating that the signaling pathway is functional. Accordingly, a subset of formalin-fixed, paraffin-embedded biopsies showed expression of phosphorylated KIT in the residue $\mathrm{Tyr}^{719}$. Active ERK $1 / 2$ was also detected by Western blotting in the same clinical samples. These results demonstrate that $\mathrm{SCF} / \mathrm{KIT} / \mathrm{ERK} 1 / 2$ pathway is active in a subset of Ewing tumors.

Additional evidence that Ewing tumor cell lines are dependent on KIT activation for proliferation is given by the marked decrease in KIT and MAPK phosphorylation levels after treating cells with imatinib, as evaluated by immunoprecipita- 
A

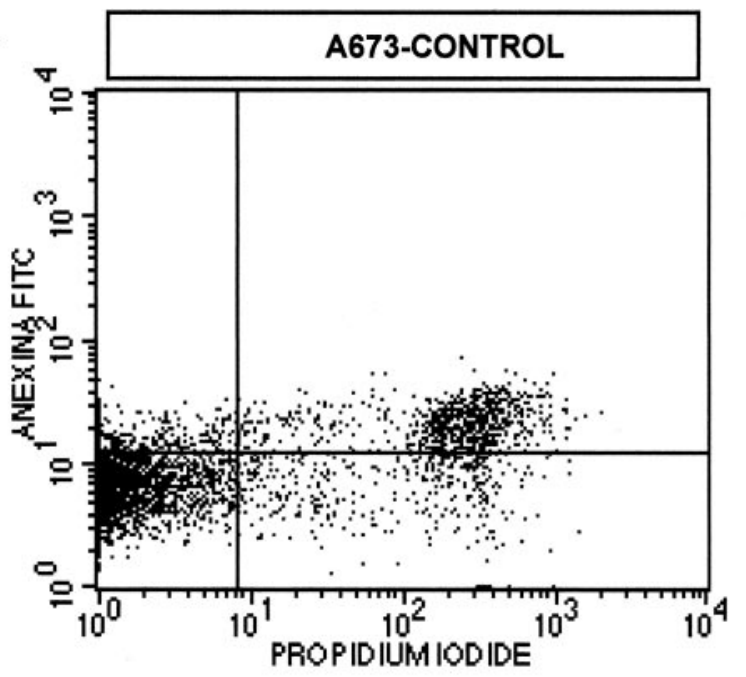

C

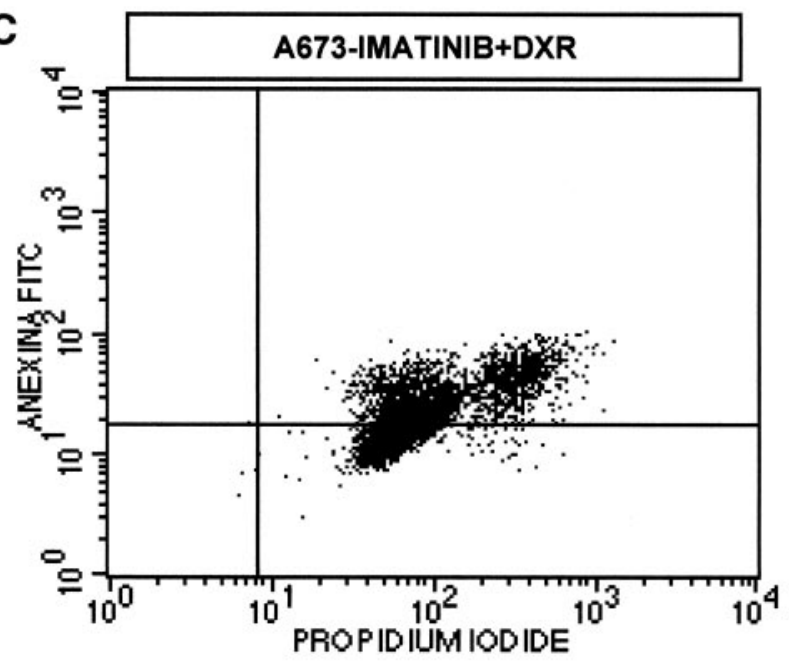

B

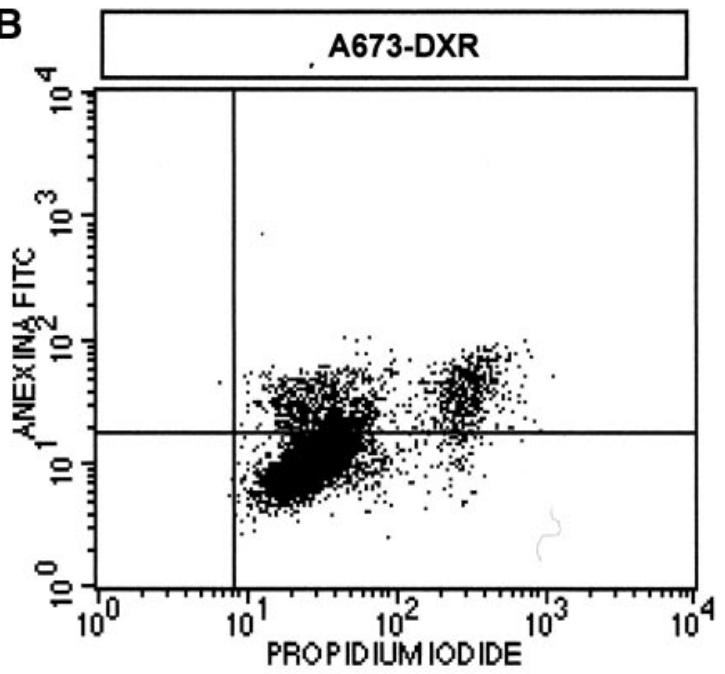

D

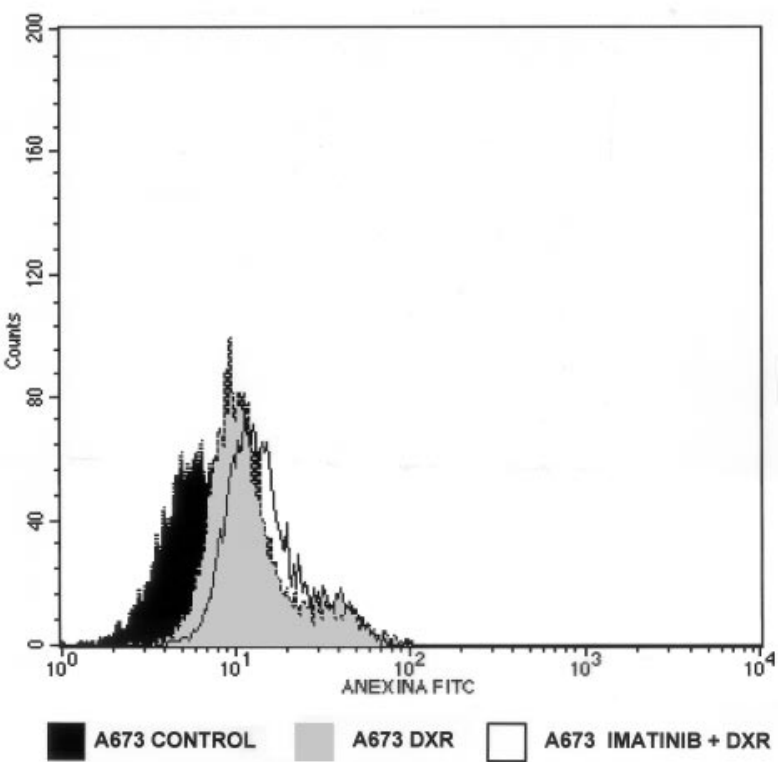

Fig. 9 Increased apoptotic levels after combined treatment with DXR and imatinib. $A-D$ represent significant flow cytometry experiments analyzing Annexin-V-FITC detection. Histograms showing Annexin-V and propidium iodide distribution in presence of FBS $(A), 10 \mu \mathrm{M}$ imatinib $(B)$, and imatinib with doxorubicin (DXR; $C$ ) are shown in the top half of the figure. The number of A673 early apoptotic cells (Annexin-V + , propidium iodide - ) increased when combined treatment was administered $(48 \%)$ with respect to DXR alone (33\%). $D$ shows curve displacement of imatinib + DXR with respect to DXR alone.

tion and Western blotting. These experiments show that the drug was able to block KIT signaling pathway activation. Moreover, proliferation assays with imatinib treatment revealed a dosedependent decrease in in vitro thymidine incorporation in all cell lines, indicating that KIT provides an important signal for proliferation in Ewing tumor cell lines. A previous study by Hotfilder et al. (44) suggested that imatinib had a low and transitory effect on the growth proliferation of several Ewing tumor cells. It is worth mentioning that this group demonstrated KIT receptor expression although did not assess its functionality. Moreover, Hotfilder et al. (45) obtained cell growth inhibition only at high doses of imatinib, which have been reported to be unspe- cific. Therefore, the possibility of the drug acting through other pathways should be considered in this particular case.

Our assays were designed to investigate the activity of imatinib in cell line models at levels similar to the approximate plasma concentrations resulting from standard dose regimen of imatinib. Therefore, combined treatments were carried out with $10 \mu \mathrm{M}$ imatinib because higher concentrations are above those maximally tolerated in Phase I clinical trials (close to 1000 $\mathrm{mg} /$ day, which correspond to $6-10 \mu \mathrm{M}$ in blood levels; Ref. 46). For example, a mean maximal concentration of $4.6 \mu \mathrm{M}$ was reached at steady state by once-daily administration of $400 \mathrm{mg}$ of imatinib in patients with chronic myelogenous leukemia (29). 
A
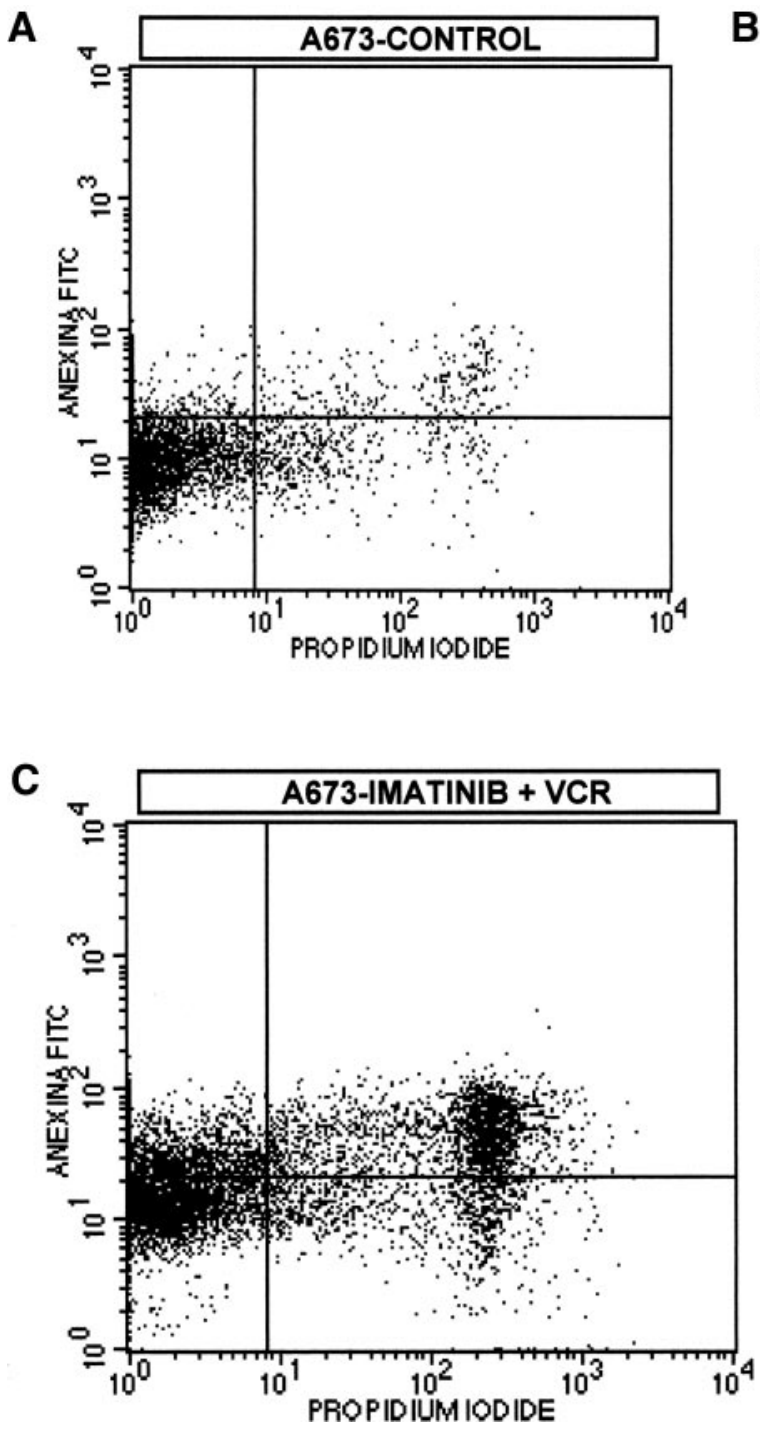

B
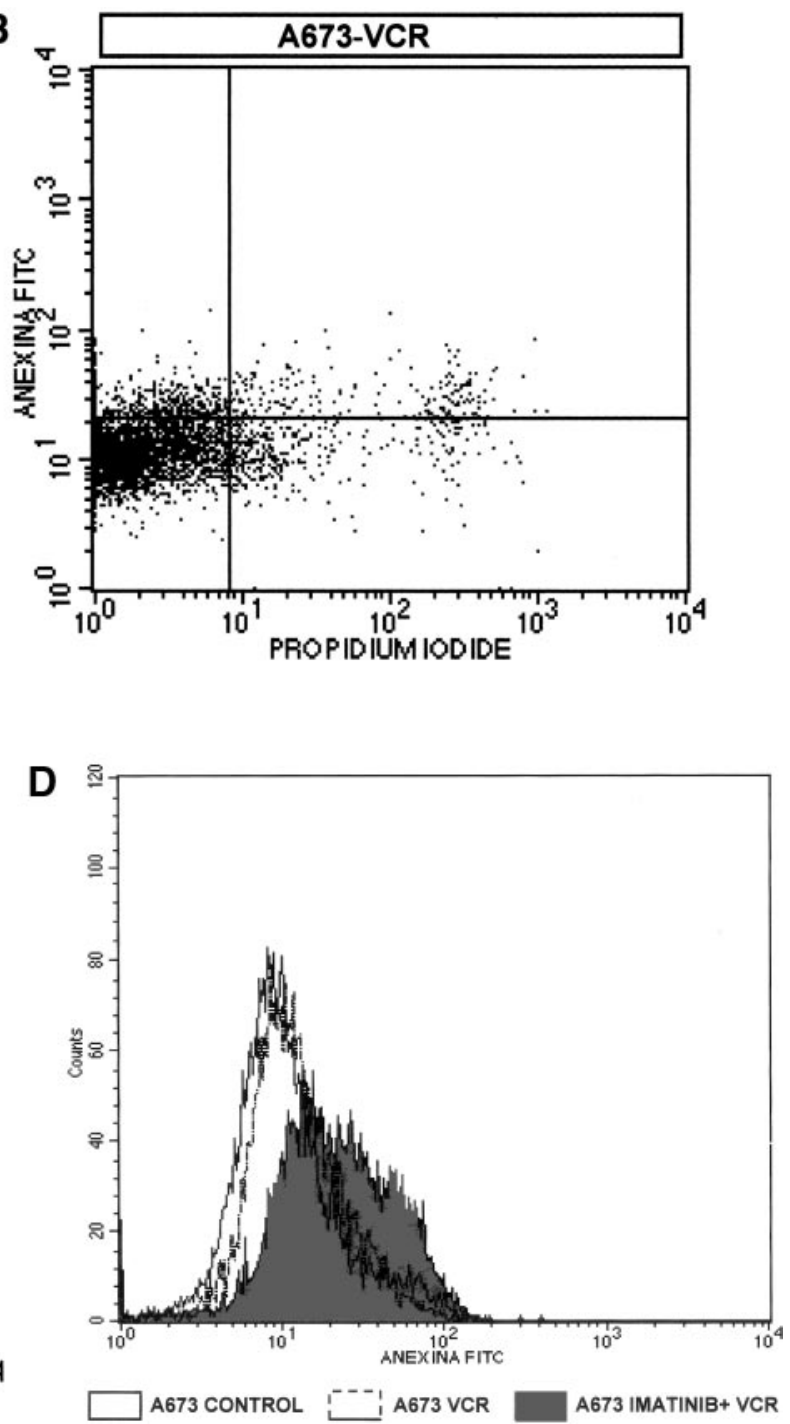

Fig. 10 Increased apoptotic levels after combined treatment with vincristine (VCR) and imatinib. $A-D$ represent significant flow cytometry experiments analyzing Annexin-V-FITC detection. Histograms showing Annexin-V and propidium iodide distribution in presence of FBS $(A), 10 \mu M$ imatinib $(B)$, and imatinib with VCR $(C)$ are shown in the top half of the figure. The number of A673 early apoptotic cells (Annexin-V + , propidium iodide - ) increases when combined treatment was administered (50\%) with respect to VCR alone (20\%). $D$ shows curve displacement of imatinib + VCR with respect to VCR alone.

Phase III clinical trials of adjuvant imatinib versus placebo in patients after the complete resection of primary GIST use doses of up to $800 \mathrm{mg} /$ day. Besides, it is known that imatinib loses some specificity at concentrations $>10 \mu \mathrm{M}$ (45). Therefore, higher concentrations of the drug induce proliferation arrest and apoptosis probably by inhibition of other tyrosine kinases. Despite consistent inhibition of cell proliferation, imatinib alone was not able to induce a significant degree of apoptosis in Ewing tumor cell lines at clinically relevant concentrations (10 $\mu \mathrm{M})$. Other authors have found an induction of apoptosis after imatinib treatment in in vitro experiments performed with lower concentrations of FBS and higher concentrations of the drug (20 $\mu \mathrm{M}$; Ref. 27). We confirmed these results but used a broader drug concentration range $(2-20 \mu \mathrm{M})$ in a broader time range to determine whether in presence of FBS, a rich growth factor microenvironment, imatinib was able to induce cell death. The $\mathrm{SCF} / \mathrm{KIT}$ pathway has been shown to protect tumor cells from apoptosis by sequential activation of phosphatidylinositol $3^{\prime}$ kinase, AKT, and BAD (47). AKT promotes cell survival and plays a critical role in controlling balance between survival and apoptosis. The absence of a significant increase of apoptosis after treatment with imatinib represents, in turn, evidence that other pathways, as for example insulin-like growth factor I receptor/phosphatidylinositol 3'-kinase/AKT, might be more relevant to Ewing tumor cell survival (48). Accordingly, our experiments showed no differences in expression and phosphorylation status of AKT in any Ewing tumor cell line after imatinib treatment. This is analogous to the results reported in 
small cell lung cancer, another solid tumor with KIT expression, in which imatinib is cytostatic and unable to induce apoptosis (49) Conversely, imatinib induces both AKT activity blockade in BCR-ABL-positive cells together with relevant levels of apoptosis (50).

One key finding of this study is that combination of imatinib with conventional drugs in Ewing tumor treatment such as DXR and VCR substantially improves their cytotoxic effect. The agents we used for the combination with imatinib were selected because they are included in nearly all conventional chemotherapeutic protocols for Ewing tumor (51). Although data suggest that KIT is not critical for Ewing tumor cell survival, blockade of the receptor made cells more susceptible to cellular damage caused by cytotoxic drugs. This effect suggests that KIT signaling pathway blockade with imatinib is not completely rescued by other growth factor signaling pathways. This is to our knowledge the first study showing benefit of combination therapy with imatinib and VCR and DXR in a solid tumor without mutations of the c-kit gene. This is, for example, in contrast to what is observed in small cell lung cancer in which high imatinib concentrations have a cytostatic effect, and combination with carboplatinum or etoposide does not trigger apoptosis (49)

The metastatic sites associated to the worst prognosis in Ewing tumor are the bone and bone marrow, two SCF-rich tissues (52). Interestingly, in a recent study (26), Ewing tumor cells injected i.v. into athymic nude mice metastasized to a variety of SCF-rich microenvironments. Metastatic cells that find an SCF-rich microenvironment may present a proliferative advantage with respect to other locations with lower concentrations of growth factors. Therefore, the use of imatinib in Ewing tumor metastatic to bone marrow or bone could be of high therapeutic interest because treatment of Ewing tumor cell lines with imatinib results in a strong inhibition in the proliferative rate that does not revert in the presence of high concentrations of exogenous SCF.

Taken together, our results demonstrate that inhibition of Ewing tumor cell proliferation by imatinib is mediated through inhibition of KIT receptor signaling and that inhibition of KIT increases sensitivity of these cells to DXR and VCR. The data suggest that clinical trials using imatinib for refractory or metastatic KIT-expressing Ewing tumor in combination with other chemotherapeutic agents may be warranted based upon these observations.

\section{ACKNOWLEDGMENTS}

We thank Drs. Navarro and Ramón y Cajal for Ewing tumor cell lines and Loli Martínez, Merche Aguirre, and Marian Martínez for technical assistance.

\section{REFERENCES}

1. de Alava, E., and Gerald, W. L. Molecular biology of the Ewing's sarcoma/primitive neuroectodermal tumor family. J. Clin. Oncol., 18: 204-213, 2000.

2. Fizazi, K., Dohollou, N., Blay, J. Y., Guerin, S., Le Cesne, A., Andre, F., Pouillart, P., Tursz, T., and Nguyen, B. B. Ewing's family of tumors in adults: multivariate analysis of survival and long-term results of multimodality therapy in 182 patients. J. Clin. Oncol., 16: 3736-3743, 1998.
3. Kushner, B. H., and Meyers, P. A. How effective is dose-intensive/ myeloablative therapy against Ewing's sarcoma/primitive neuroectodermal tumor metastatic to bone or bone marrow? The Memorial SloanKettering experience and a literature review. J. Clin. Oncol., 19: 870$880,2001$.

4. Delattre, O., Zucman, J., Plougastel, B., Desmaze, C., Melot, T., Peter, M., Kovar, H., Joubert, I., de Jong, P., Rouleau, G., Aurias, A., and Thomas, G. Gene fusion with an ETS DNA-binding domain caused by chromosome translocation in human tumours. Nature (Lond.), 359: $162-165,1992$.

5. Zucman, J., Delattre, O., Desmaze, C., Plougastel, B., Joubert, I., Melot, T., Peter, M., De Jong, P., Rouleau, G., Aurias, A., and Thomas, G. Cloning and characterization of the Ewing's sarcoma and peripheral neuroepithelioma $\mathrm{t}(11 ; 22)$ translocation breakpoints. Genes Chromosomes Cancer, 5: 271-277, 1992.

6. Sorensen, P. H., Lessnick, S. L., Lopez-Terrada, D., Liu, X. F., Triche, T. J., and Denny, C. T. A second Ewing's sarcoma translocation, $\mathrm{t}(21 ; 22)$, fuses the EWS gene to another ETS-family transcription factor, ERG. Nat. Genet., 6: 146-151, 1994.

7. Jeon, I. S., Davis, J. N., Braun, B. S., Sublett, J. E., Roussel, M. F., Denny, C. T., and Shapir, D. N. A variant Ewing's sarcoma translocation $(7 ; 22)$ fuses the EWS gene to the ETS gene ETV1. Oncogene, 10: 1229-1234, 1995.

8. Urano, F., Umezawa, A., Hong, W., Kikuchi, H., and Hata, J. A novel chimera gene between EWS and E1A-F, encoding the adenovirus E1A enhancer-binding protein, in extraosseous Ewing's sarcoma. Biochem. Biophys. Res. Commun., 219: 608-612, 1996.

9. May, W. A., and Denny, C. T. Biology of EWS/FLI and related fusion genes in Ewing's sarcoma and primitive neuroectodermal tumor. Curr. Top. Microbiol. Immunol., 220: 143-150, 1997.

10. Peter, M., Couturier, J., Pacquement, H., Michon, J., Thomas, G., Magdelenat, H., and Delattre, O. A new member of the ETS family fused to EWS in Ewing tumors. Oncogene, 14: 1159-1164, 1997.

11. Ishida, S., Yoshida, K., Kaneko, Y., Tanaka, Y., Sasaki, Y., Urano, F., Umezawa, A., Hata, J., and Fujinaga, K. The genomic breakpoint and chimeric transcripts in the EWSR1-ETV4/E1AF gene fusion in Ewing sarcoma. Cytogenet. Cell Genet., 82: 278-283, 1998.

12. May, W., Arvand, A., Thompson, A., Braun, D., Wright B. S., and Denny, M. C. T. EWS/FLI1-induced manic fringe renders NIH 3T3 cells tumorigenic. Nat. Genet., 17: 495-497, 1997.

13. Tanaka, K., Iwakuma, T., Harimaya, K., Sato, H., and Iwamoto, Y. EWS-Fli1 antisense oligodeoxynucleotide inhibits proliferation of human Ewing's sarcoma and primitive neuroectodermal tumor cells. J. Clin. Investig., 99: 239-247, 1997.

14. Scotlandi, K., Benini, S., Nanni, P., Lollini, P. L., Nicoletti, G., Landuzzi, L., Serra, M., Manara, M. C., Picci, P., and Baldini, N. Blockage of insulin-like growth factor-I receptor inhibits the growth of Ewing's sarcoma in athymic mice. Cancer Res., 58: 4127-4131, 1998. 15. Lawlor, E. R., Lim, J. F., Tao, W., Poremba, C., Chow, C. J., Kalousek, I. V., Kovar, H., MacDonald, T. J., and Sorensen, P. H. The Ewing tumor family of peripheral primitive neuroectodermal tumors expresses human gastrin-releasing peptide. Cancer Res., 58: $2469-$ 2476, 1998.

16. Rottapel, R., Reedijk, M., Williams, D. E., Lyman, S. D., Anderson, D. M., Pawson, T., and Bernstein, A. The Steel/W transduction pathway: kit autophosphorylation and its association with a unique subset of cytoplasmic signaling proteins is induced by the Steel factor. Mol. Cell. Biol., 11: 3043-3051, 1991.

17. Furitsu, T., Tsujimura, T., Tono, T., Ikeda, H., Kitayama, H., Koshimizu, U., Sugahara, H., Butterfield, J. H., Ashman, L. K., and Kanayama, Y. Identification of mutations in the coding sequence of the proto-oncogene c-kit in a human mast cell leukemia cell line causing ligand-independent activation of c-kit product. J. Clin. Investig., 92: 1736-1744, 1993.

18. Fukuda, T., Kamishima, T., Tsuura, Y., Suzuki, T., Kakihara, T., Nai, M., Kishi, K., Matsumoto, K., Shibata, A., and Seito, T. Expression of the c-kit gene product in normal and neoplastic mast cells but not in 
neoplastic basophil/mast cell precursors from chronic myelogenous leukaemia. J. Pathol., 177: 139-146, 1995.

19. Nakata, Y., Kimura, A., Katoh, O., Kawaishi, K., Hyodo, H., Abe, K., Kuramoto, A., and Satow, Y. c-kit point mutation of extracellular domain in patients with myeloproliferative disorders. Br. J. Haematol., 91: 661-663, 1995.

20. Tian, Q., Frierson, H. F., Jr., Krystal, G. W., and Moskaluk, C. A. Activating c-kit gene mutations in human germ cell tumors. Am. J. Pathol., 154: 1643-1647, 1999.

21. Taniguchi, M., Nishida, T., Hirota, S., Isozaki, K., Ito, T., Nomura, T., Matsuda, H., and Kitamura, Y. Effect of c-kit mutation on prognosis of gastrointestinal stromal tumors. Cancer Res., 59: 4297-4300, 1999. 22. Lux, M. L., Rubin, B. P., Biase, T. L., Chen, C. J., Maclure, T., Demetri, G., Xiao, S., Singer, S., Fletcher, C. D., and Fletcher, J. A. KIT extracellular and kinase domain mutations in gastrointestinal stromal tumors. Am. J. Pathol., 156: 791-795, 2000.

23. Rubin, B. P., Singer, S., Tsao, C., Duensing, A., Lux, M. L., Ruiz, R., Hibbard, M. K., Chen, C. J., Xiao, S., Tuveson, D. A., Demetri, G. D., Fletcher, C. D., and Fletcher, J. A. KIT activation is a ubiquitous feature of gastrointestinal stromal tumors. Cancer Res., 61: 8118-8121, 2001.

24. Heinrich, M. C., Blanke, C. D., Druker, B. J., and Corless, C. L. Inhibition of KIT tyrosine kinase activity: a novel molecular approach to the treatment of KIT-positive malignancies. J. Clin. Oncol., 20: 16921703, 2002.

25. Smithey, B. E., Pappo, A. S., and Hill, D. A. c-kit expression in pediatric solid tumors: a comparative immunohistochemical study. Am. J. Surg. Pathol., 26: 486-492, 2002.

26. Landuzzi, L., De Giovanni, C., Nicoletti, G., Rossi, I., Ricci, C., Astolfi, A., Scopece, L., Scotlandi, K., Serra, M., Bagnara, G. P., Nanni, P., and Lollini, P. L. The metastatic ability of Ewing's sarcoma cells is modulated by stem cell factor and by its receptor c-kit. Am. J. Pathol., 157: 2123-2131, 2000.

27. Merchant, M. S., Woo, C. W., Mackall, C. L., and Thiele, C. J. J. Potential use of imatinib in Ewing's sarcoma: evidence for in vitro and in vivo activity. J. Natl. Cancer Inst. (Bethesda), 94: 1673-1679, 2002. 28. Horita, M., Andreu, E. J., Benito, A., Arbona, C., Sanz, C., Benet, I., Prosper, F., and Fernandez-Luna, J. L. Blockade of the Bcr-Abl kinase activity induces apoptosis of chronic myelogenous leukemia cells by suppressing signal transducer and activator of transcription 5dependent expression of Bcl-xL. J. Exp. Med., 191: 977-984, 2000.

29. Druker, B. J., Talpaz, M., Resta, D. J., Peng, B., Buchdunger, E., Ford, J. M., Lydon, N. B., Kantarjian, H., Capdeville, R., Ohno-Jones, S., and Sawyers, C. L. Efficacy and safety of a specific inhibitor of the BCR-ABL tyrosine kinase in chronic myeloid leukemia. N. Engl. J. Med., 344: 1031-1037, 2001.

30. Savage, D. G., and Antman, K. H. Imatinib mesylate: a new oral targeted therapy. N. Engl. J. Med., 346: 683-693, 2002.

31. Berman, J. T., and O'Leary, T. J. Gastrointestinal stromal tumor workshop. Hum. Pathol., 32: 578-582, 2001.

32. Joensuu, H. Treatment of inoperable gastrointestinal stromal tumor (GIST) with imatinib (Glivec, Gleevec). Med. Klin., 97 (Suppl. 1): 28-30, 2002.

33. de Alava, E., Kawai, A., Healey, J. H., Fligman, I., Meyers, P., Huvos, A. G., Gerald, W. L., Jhanwar, S. C., Argani, P., Antonescu, C. R., Pardo-Mindan, F. J., Ginsberg, J., Womer, R., Lawlor, E. R., Wunder, J., Andrulis, I., Sorensen, P. H. B., Barr, F. G., and Ladanyi, M. EWS-FLI1 fusion transcript structure is an independent determinant of prognosis in Ewing's sarcoma. J. Clin. Oncol., 16: 1248-1255, 1998. 34. Martin, F. H., Suggs, S. V., Langley, K. E., Lu, H. S., Ting, J., Okino, K. H., Morris, C. F., McNiece, I. K., Jacobsen, F. W., Mendiaz, E. A., et al. Primary structure and functional expression of rat and human stem cell factor DNAs. Cell, 63: 203-211, 1990.

35. Reith, A. D., Ellis, C., Lyman, S. D., Anderson, D. M., Williams, D. E., Bernstein, A., and Pawson, T. Signal transduction by normal isoforms and $\mathrm{W}$ mutant variants of the Kit receptor tyrosine kinase. EMBO J., 10: 2451-2459, 1991.

36. Zhu, W. M., Dong, W. F., and Minden, M. Alternate splicing creates two forms of the human kit protein. Leuk. Lymphoma, 12: 441-447, 1994.

37. Wypych, J., Bennett, L. G., Schwartz, M. G., Clogston, C. L., Lu, H. S., Broud, V. C., Bartley, T. D., Parker, V. P., and Langley, K. E. Soluble kit receptor in human serum. Blood, 85: 66-73, 1995.

38. Miyazawa, K., Williams, D. A., Gotoh, A., Nishimak, J., Broxmeyer, H. E., and Toyama, K. Membrane-bound Steel factor induces more persistent tyrosine kinase activation and longer life span of c-kit geneencoded protein than its soluble form. Blood, 85: 641-649, 1995.

39. Crosier, P. S., Ricciardi, S. T., Hall, L. R., Vita, M. R., Clark, S. C., and Crosier, K. E. Expression of isoforms of the human receptor tyrosine kinase c-kit in leukemic cell lines and acute myeloid leukemia. Blood, 82: 1151-1158, 1993.

40. Andersson, J., Sjogren, H., Meis-Kindblom, J. M., Stenman, G., Aman, P., and Kindblom, L. G. The complexity of KIT gene mutations and chromosome rearrangements and their clinical correlation in gastrointestinal stromal (pacemaker cell) tumors. Am. J. Pathol., 160: 15-22, 2002.

41. Corless, C. L., and Heinrich, M. C. KIT gene mutations in gastrointestinal stromal tumors: more complex than previously recognized. Am. J. Pathol., 161: 737-739, 2002.

42. Hornick, J. L., and Fletcher, C. D. Immunohistochemical staining for KIT (CD117) in soft tissue sarcomas is very limited in distribution. Am. J. Clin. Pathol., 117: 188-193, 2002.

43. de Alava, E., Panizo, A., Antonescu, C. R., Huvos, A. G., PardoMindan, F. J., Barr, F. G., and Ladanyi, M. Association of EWS-FLI1 type 1 fusion with lower proliferative rate in Ewing's sarcoma. Am. J. Pathol., 156: 849-855, 2002.

44. Hotfilder, M., Lanvers, C., Jürgens, H., Boos, J., and Vormoor, J. c-kit-expressing Ewing tumor cells are insensitive to imatinib mesylate (STI571). Cancer Chemother. Pharmacol., 50: 167-169, 2002.

45. Krystal, G. W. Mechanisms of resistance to imatinib (STI571) and prospects for combination with conventional chemotherapeutic agents. Drug Resist. Updat., 4: 16-21, 2001.

46. Mauro, M. J., and Druker, B. J. STI 571: targeting BCR-ABL as therapy for CML. Oncologist, 6: 233-238, 2001.

47. Blume-Jensen, P., Janknecht, R., and Hunter, T. The kit receptor promotes cell survival via activation of PI 3-kinase and subsequent Akt-mediated phosphorylation of Bad on Ser ${ }^{136}$. Curr. Biol., 8: 779782, 1998.

48. Toretsky, J. A., Thakar, M., Eskenazi, A. E., and Frantz, C. N. Phosphoinositide 3-hydroxide kinase blockade enhances apoptosis in the Ewing's sarcoma family of tumors. Cancer Res., 59: 5745-5750, 1999.

49. Krystal, G. W., Honsawek, S., Litz, J., and Buchdunger, E. The selective tyrosine kinase inhibitor STI571 inhibits small cell lung cancer growth. Clin. Cancer Res., 6: 3319-3326, 2000.

50. Fang, G., Kim, C. N., Perkins, C. L., Ramadevi, N., Winton, E., Wittmann, S., and Bhalla, K. N. CGP57148B (STI-571) induces differentiation and apoptosis and sensitizes Bcr-Abl-positive human leukemia cells to apoptosis due to antileukemic drugs. Blood, 96: 2246-2253, 2000.

51. Grier, H. E., Krailo, M. D., Tarbell, N. J., Link, M. P., Fryer, C. J., Pritchard, D. J., Gebhardt, M. C., Dickman, P. S., Perlman, E. J., Meyers, P. A., Donaldson, S. S., Moore, S., Rausen, A. R., Vietti, T. J., and Miser, J. S. Addition of ifosfamide and etoposide to standard chemotherapy for Ewing's sarcoma and primitive neuroectodermal tumor of bone. N. Engl. J. Med., 20: 694-701, 2003.

52. Dormady, S. P., Bashayan, O., Dougherty, R., Zhang, X. M., and Basch, R. S. Immortalized multipotential mesenchymal cells and the hematopoietic microenvironment. J. Hematother. Stem Cell Res., 10: 125-140, 2001. 